\title{
Legal Protection of Persons with Disabilities in Signing And Affixing Fingerprints To The Notary Deed Minutes
}

\author{
Akmal Budi1, Kartina Pakpahan ${ }^{2}$, Elvira Fitriyani Pakpahan ${ }^{3}$. Heriyanti $^{4}$, O.K. Isnainul ${ }^{5}$ \\ \{amalbudi60@gmail.com¹, kartinapakpahan@unprimdn.ac.id², elvirapakpahan@unprimdn.ac.id ${ }^{3}$, \\ heriyanti@unprimdn.ac.id ${ }^{4}$,okisnainul@unprimdn.ac.id $\left.{ }^{5}\right\}$ \\ Universitas Prima Indonesia, Indonesia ${ }^{12345}$
}

\begin{abstract}
After the enactment of Law Number 2 of 2014, specifically the obligation of sticking fingerprinting on the minutes of the deed has caused various polemics, because the mechanism for implementing fingerprinting sticking is not yet available, while the explanation of Article 16 paragraph (1) letter c of Law Number 2 Year 2014 was only written quite clearly. Therefore, between one notary and another notary in applying it. The problem in this research is the procedure for affixing the fingerprints of the parties to the notary deed minutes according to Law Number 2 of 2014 concerning Amendment of Law Number 30 of 2004 concerning Notary Position. The legal implications of fingerprinting of the parties to the notary deed minutes, and the authenticity of the notary deed in relation to disability not signing and affixing fingerprints to the minutes of the deed? This research is normative and empirical juridical. Normative juridical research refers to laws and regulations, whereas empirical research is obtained in the field. The result of the research is that according to Article 16 paragraph (1) letter c of law number 2 of 2014, a Notary is required to attach a fingerprint on the deed the notary asks the user to put right and left fingerprints (thumb / thumb) attached to the minutes of the deed, although there is no prohibition if there is a notary who attaches the fingerprints of the minutes of the deed with a finger other than the thumb, because there is no further explanation in the Notary Position Act concerning which fingerprints are attached to the minutes of the deed. The use of fingerprints on the minutes of deed based on is not a substitute for signature as referred to in Article 1874 of the Indonesia Civil Code. The legal implications if the fingerprints of the notary deed are included, which will provide more legal certainty because each person has a different fingerprint, so that if in the future a dispute occurs, the relevant party cannot deny it. Fingerprinting will also provide more legal force to the notary deed product, so that it will have an impact on more legal protection for the parties concerned, the notary and third parties, and can maintain administrative order. Legal Implications if fingerprints are not affixed to the minutes of the deed in accordance with Article 16 paragraph (1) letter c of Law Number 2 of 2014, the Notary may be subjected to administrative sanctions due to not fulfilling the Notary's obligations in carrying out office duties in the form of obligations contained in the Law Position of Notary Public. If the user cannot put a fingerprint, the reason must be stated clearly and stated clearly indeed so that the deed will not lose authenticity. The deed remains legally valid and has a value as an authentic deed.
\end{abstract}

Keywords: Notary; Fingerprint; Deed Minutes 


\section{Preliminary}

The Republic of Indonesia as a constitutional state based on Pancasila and the 1945 Constitution of the Republic of Indonesia guarantees legal certainty, order, and protection for every citizen. To ensure legal certainty, order and protection, authentic written evidence is required regarding legal acts, agreements, decrees, and events made before or by an authorized official. Legal provisions must follow the development of people's lives so that they do not become rigid, not only as a sleeping law or even a dead law. Therefore, the State of Indonesia as a rule of law whose society continues to develop in terms of science and technology has brought major changes, so it is necessary to also make changes to various existing regulations to harmonize people's lives. One of the regulations that has undergone amendments is the regulation of Law Number 30 of 2004 concerning the Position of Notary, (in lieu of Regulation of the Position of Notary of Staatsblad Number 3 of 1860 or Reglement op Het Notary Ambt in Indonesie, which was a regulation of the Dutch Colonial Government). Then on January 17, 2014, Law Number 2 of 2014 concerning Amendment Number 30 of 2004 concerning the Position of Notary was promulgated.

Amendment of Law Number 30 of 2004 to Law Number 2 of 2014, one of which is the obligation to affix the fingerprint of the person to the minutes of the deed, regulated in Article 16 paragraph (1) letter $\mathrm{c}$ which states: In carrying out his office, the Notary must: affix letters and documents as well as the fingerprints of the face on the Minutes of the Act. Provisions of the obligation to affix the fingerprint of the face to the minutes of the deed, previously not regulated stated in the Staatsblad Notary Office Regulation Number 3 of 1860 and in Law Number 30 of 2004. Article 28 of the Staatsblad Notary Position Regulation Number 3 of 1860 states: Immediately afterwards, the deed must be signed by all the parties, unless it is determined that they cannot sign their signature or are unable to do so, in this case their statement and the reason for the obstruction should be explicitly stated in the act. Article 44 paragraphs (1) and (2) of Law Number 30 of 2004 states:

a. Immediately after the deed is read, the deed is signed by each attendee, witness, and

Notary, except if there is a witness who is unable to sign by stating the reasons.

b. The reasons as referred to in paragraph (1) shall be clearly stated in the deed.

The position of the face of the face in the Staatsblad Notary Office Regulation No. 3 of 1860 and Law No. 30 of 2004 is in lieu of the signature if the face is obstructed in affixing his signature, can be equated with the signature of the face and shows that the person is considered to have known, understood, understand, and agree to what is the content of the deed and bind himself to the deed. Article 1874 Civil Code (hereinafter referred to as the Civil Code) states:

The signing of a negotiated document is equated with a fingerprint attached thereto, authenticated by a dated statement from a civil-law notary or another official to be designated by ordinance, showing that he knows the author of the fingerprint, or that it has been made known to him. that the content of the deed is known to the author of the fingerprint, or that it has been made known to him, that the content of the deed is clearly presented to the author of the fingerprint, and that afterwards the fingerprint is made in the opposition of the official. The officer books the document.

The shift in the meaning of affixing the face fingerprint in the Staatsblad Notary Office Regulation Number 3 of 1860, Law Number 30 of 2004 and the Civil Code, that the face fingerprint is not an obligation but only in lieu of the face of the face, if obstructed when affixing his signature on a deed, after the promulgation of the Law- Law Number 2 of 2014, the fingerprint of the face becomes an obligation that explains that the face has actually faced 
a Notary and signed the deed. After the enactment of Law Number 2 of 2014, especially the obligation to affix the fingerprint of the face to the minutes of the deed has caused various polemics, because the implementation mechanism of affixing the fingerprint of the face does not exist, while Article 16 paragraph (1) letter $\mathrm{c}$ of Law Number 2 of 2014 , just written quite clearly.

Therefore, between one Notary and another Notary differs in applying it. Some Notaries affix the fingerprint of the face on their own sheet and affixed to the minutes of the deed, but there are also some Notaries who affix the fingerprint of the face directly on the minutes of the deed. Other provisions such as the finger facing which part (thumbprint/thumbprint or three fingerprint) and affixed using ink or can also by using fingerprints, have not been determined in detail.

On the issue, a Plenary Meeting of the Central Board of the Indonesian Notary Association was held, which expanded the supply and refreshing of knowledge on Law Number 2 of 2014: A New Paradigm for Notaries Towards Full Professionalism Through Accuracy, Accuracy and Knowledge held in Jakarta on Monday 24 March 2014. One of the results of the meeting decided the fingerprint of the face taken was the right thumbprint. When the right thumb is problematic then the Notary can take the fingerprint of the face from the other finger. The Chairman of the Board of Directors of the Indonesian Notary Association stressed that the provision of the fingerprint of the face, namely the right thumbprint, is not a new norm but an agreement from the organization.

The first concept of proof is relevant, meaning that it is related to facts that point to an event. The second is admissible, meaning that the evidence must be accepted. Third, namely exclusionary rules, as a legal principle that requires the non-recognition of evidence obtained against the law. Fourth, namely the weight of the evidence, in the context of the court every relevant and acceptable evidence must be evaluated by a judge, in such a context it enters the power of evidence.

Regarding the four things of the concept of proof, Max M. Houck stated that there are two types of evidence that cannot strengthen a case. First, if there is a conflict of evidence between one another, which evidence comes from different sources and cannot be referenced. Second, the evidence is not can be used because it was obtained illegally, which is called tainted evidence. Included in tainted evidence is derivative evidence or evidence that is not original. Evidence in civil cases, especially in Indonesia is inseparable from Book IV of the Civil Code which governs the Evidence and Expiration in Article 1866 states that:

Evidence tools consist of: written evidence; evidence with witnesses; suspicions; confession; oath; everything by observing the rules set out in the following chapters. An act is a letter or writing to be used as evidence of an event and signed by the maker. An authentic act or an official act based on Article 1868 of the Civil Code is: An authentic act is an act in the form prescribed by law, made by or in the presence of public officers authorized for it at the place where the act is made. The general officials in question are Notaries, Judges, Civil Registration Officers (ambtenaar burgerlijk stand), President, Minister, Guberbur, Regent, Sub -District Head, Marriage Registrar, Court Clerk, Bailiff, and so on.

By law, an authentic deed has perfect proof (volledig bewijs) meaning that if a party files an authentic deed, the judge must accept it and assume that what is written in the deed has happened so that the judge cannot order additions. proof again. Because proof by deed is indeed the most important means of proof, then this tool of proof by law is referred to as the number one means of proof. Similarly, for some acts or agreements that are considered very important require the making of a deed, such as Article 1851 of the Criminal Code which in essence requires that a peace must at least be proven by a deed under hand. The legal actions 
of the deed of establishment and deed of amendment to the articles of association of a Limited Liability Company, according to Article 7 of Law Number 1 of 1995 (previously Article 38 of the Indonesian Commercial Code), which have been amended to Law Number 40 of 2007 concerning Limited Liability Companies. Article 1868 of the Civil Code tries to provide a definition (definition) of authentic deeds, but it does not explain who is meant by a public official, nor does it explain the extent of his authority and the place where he is authorized in such a manner, as well as how the form of a deed is determined by law. It is a must to make a notary a public official in relation to the definition of an authentic deed provided by Article 1868 of the Civil Code.

The inclusion of general words in the term public official, apart from being in line with the will of Article $1868 \mathrm{KUHPdt}$, is also to provide legitimacy and give a special mark when compared to other officials. This means that it is to distinguish clearly and clearly, the attributes of officials who have very specific authority compared to other officials who even hold the title of official. If according to general regulations, the general term "authentic deed" means that it must be interpreted as a notary deed, unless it is expressly excluded from and under the authority of another official, or by general regulations, it is confirmed that the authority for that is also given to another official. As for the deeds of manufacture are also assigned to other officials or by law, they are exempted from making them, among others:

1. Certificate of recognition of children outside of marriage (Article 281 Civil Code);

2. Deed of minutes of negligence of mortgage depositors (Article 1227 Civil Code);

3. Deed of minutes regarding offers of cash and consignment payments (Articles 1405 and 1406 of the Civil Code);

4. Deed of protest of money orders and post (Articles 143 and 218 of the commercial law code);

5. Civil Registry Deed (Article 4 Civil Code);

6. Deed of Land Deed Making Official (Article 1 point 4 of the Regulation on the Position of Land Deed Making Official). Civil Registry Office employees even for legal acts which become their authority to make the authentic deed, exclude the Notary from making it. They then do not become public officials or become Notaries, but they retain their positions and professions as employees of the Civil Registry office.

Looking further into the authentic deed made by an authorized official other than the Notary, in the rules of his department does not require the affixing of fingerprints on the authentic deed made by him. Regulation of the Head of the National Land Agency Number 1 of 2006 on the Provisions for the Implementation of Government Regulation Number 37 of 1998 on the Regulation of the Official Position of Land Deed Maker (hereinafter referred to as the regulation concerning the Position of Land Deed Making Official)) Article 53 states that:

1. The Deed of the Land Deed Making Office is made by filling in the blank of the available deed in full according to the filling instructions.

2. Filling in the deed blank in the framework of making the deed of the Land Deed Making Official, as referred to in paragraph (1) must be done in accordance with the incident, status and correct data and supported by documents in accordance with legislation.

3. The making of the deed of the Land Deed Making Office is done in the presence of 2 (two) witnesses who testified on:

a. Identity and certainty of the audience.

b. The presence of the parties or their powers.

c. The authenticity of the physical data and the juridical data of the object of the legal act in the case of the object before it is registered.

d. The existence of the document indicated in the making of the deed. 
e. The legal act has been executed by the parties concerned.

4. Who can be a witness is a person who has qualified in accordance with the legislation? The above article does not mention the obligation to affix fingerprints in the deed of the Land Deed Making Office, and from what the author has observed in the deed of the Land Deed Making Office act such as the land sale and purchase deed does not contain the fingerprints. Another example is the birth certificate as one of the products of the Civil Record deed, it can be observed that the birth certificate also does not contain a fingerprint. Based on the above background, the authors are interested in conducting research with the title Legal Protection Against Persons with Disabilities in Signing and Affixing Fingerprints on the Minutes of the Notary Deed.

\section{Problem Statement}

1. What is the procedure for fingerprinting the witnesses on the minutes of the Notary deed according to Law Number 2 of 2014 on Amendments to Law Number 30 of 2004 on the Notary Office?

2. What are the legal implications of fingerprinting the witnesses on the minutes of the Notary's deed?

3. How is the authenticity of the Notary deed in relation to the person with a disability not signing and affixing a fingerprint on the minutes of the deed?

\section{Research Objectives}

1. To analyze and find out how the procedure for fingerprint of the audience on the minutes of the Notary deed according to Law Number 2 of 2014 on Amendments to Law Number 30 of 2004 on the Notary Office

2. To analyze and find out the legal implications of fingerprint of the audience on the minutes of the Notary deed

3. To analyze and find out the authenticity of the Notary deed in relation to the person with a disability not signing and affixing a fingerprint on the minutes of the deed

\section{Research Benefits}

Through this research is expected to provide benefits:

1. Theoretically

As an input material in the field of legal science for academics on Notarial Law, and is expected to provide input for the completion of legal regulations on Legal Protection Against Disabilities in Signing and Fingerprinting on Notary Deed Minutes.

2. Practically

This research can be used as input for the Government, Notaries and the public in relation to Legal Protection for Persons with Disabilities in Signing and Fingerprinting on the Minutes of Notary Deeds.

\section{Theoretical and Conceptual Framework}

1. State Theory of Law

Plato sparked the idea of a legal state by stating that a state good is a country based on the existence of a good legal arrangement, which is called the term "nomoi". The concept of a rule of law adopted by the Unitary State of the Republic of Indonesia is the Continental European legal system (Rechtsstaat). The characteristics of Rechtsstaat are:

a. There is a constitution or constitution which contains written provisions regarding the relationship between the ruler and the people. 
b. There is a division of state power.

c. The people's rights are recognized and protected.

d. Immanuel Kant and Frederich Julius Stahl stated that the concept of the rule of law, Rechtsstaat, has 4 (four) main elements, namely:

- Recognition and protection of human rights.

- The state is based on the trias politic theory (the distribution of power);

- Legality (related to governance carried out based on law or in other words every action must be based on the law that has been implemented beforehand);

- There is a judiciary in charge of handling cases of illegal acts by the government.

e. The state of Indonesia is a state of law. This is based on the provisions of Article 1 paragraph (3) of the 1945 Constitution of the Republic of Indonesia.

2. The Principle of Legal Certainty

Normative legal certainty is when a regulation is made and promulgated because it regulates clearly and logically. It is clear in the sense that it does not cause doubts (multiinterpretation) and is logical in the sense that it becomes a system of norms with other norms so that it does not clash or create norms conflict or even a norm vacuum. Conflicts of norms that result from uncertainty of rules can take the form of norm contestation, norm reduction or norm distortion.

To achieve legal certainty, the community makes agreements in civil law traffic, one of which is the existence of legal certainty regarding the authenticity of the signing of notarial deeds carried out by an offender who has physical deficiencies (hand organs) and how then the deed can guarantee legal certainty for the parties, so as not to cause a vacuum of norms, which leads to wrongdoing. interpretation from the wider community.

3. Asas Pactasuntservanda

The principle of pactasuntservanda is the principle that a contract legally entered into by the parties binds the parties in full accordance with the contents of the contract. The position of the parties in this principle must be balanced so that there is legal certainty, if there is no balance this agreement can be revoked. With the certainty of this law, of course, also avoids the ambiguity of norms and emptiness of norms that occur, including in the case of faces with physical disabilities can still perform legal acts because the agreement is basically the agreement of the parties and the will of the parties so there is no exception for faces with disabilities. physically to be able to make an agreement.

4. Utilitarianis metheory

Jerem Bentham's utilitarianism as the greatest happiness fot the great est number means happiness as much as possible for as much as possible. This trend provides a norm that the good and bad of an action are the result of the action itself. If associated with the duties of a notary as a public official who serves the public then the act must be in accordance with existing rules so as not to cause conflict by the parties or then legal disputes and can be used as a reference in ratifying deeds done if the person has a physical disability.

5. Theory of Legal Protection

Philip M. Hadjon mentions that legal protection includes two things. Preventive legal protection includes actions that lead to efforts to prevent disputes while repressive protection means protection that is more towards efforts to resolve disputes, such as the settlement of disputes in court. An authentic deed is made essentially as a means of evidence if later there is a dispute in the future, this is one of the preventive legal protection measures. 


\section{Conceptual Framework}

1. Signature Concept

Etymologically signing (onderteken) is to sign (sign) under something. According to $\mathrm{Mr}$. C. JJ. De Joncheere's signature cannot stand alone based on the word onderteken, which is to make a sign below. Which means that signing must be done under something called writing. Tan Thong Kie defines a signature as a statement of willingness from the author of the signature, that he wants the writing written in a letter in law to be considered as his own writing by affixing the signature under the writing. Tan Thong Kie said that "to put his signature" means that what is affixed in the writing or deed is a sign of someone's hand, so it can be in the form of a signature or a thumbprint / fingerprint.

2. Concept of Disability (Persons with Disabilities) Definition and classification of persons with disabilities:

a. Government Regulation Number 36 of 1980 concerning Social Welfare Enterprises for Persons with Disabilities states that: A person with a disability is a person who according to medical science is declared to have a physical or mental disability which therefore constitutes an obstacle or obstacle for him to carry out activities properly. Consists of: disabilities, visual disabilities, mental disabilities, deaf speech and disabilities from chronic diseases.

b. Law Number 4 of 1997 concerning Persons with Disabilities which was promulgated on February 28, 1997 in the State Gazette of the Republic of Indonesia of 1997 Number 9, Supplement to the State Gazette Number 3670 concerning persons with disabilities stipulates the following definitions of persons with disabilities:

Persons with disabilities are every person who has physical and / or instrumental disabilities, which can interfere or constitute an obstacle and obstacle for him to do properly, which consists of Persons with physical disabilities, People with mental disabilities, People with physical and mental disabilities.

\section{Research Methods}

\section{Type and Nature of Research}

This research is a type of empirical normative legal research. Empirical normative legal research is a combination of normative legal research with the addition of various empirical elements. Normative legal research is legal research carried out by reviewing the laws and regulations that apply or are applied to a particular legal issue. Normative legal research is a scientific procedure to find the truth based on the scientific logic of law from its normative side. Empirical legal research is legal research that functions to be able to see the law in a real sense and to examine how the law works in a society.

Therefore, this normative-empirical legal research is about the implementation of normative legal provisions (laws) in action in every legal event that occurs in a society. The methods used in this research are as follows:

\section{Research Approach}

The approach used in this research is:

1. Historical Approach (Historical Aprroach)

Interpretation or interpretation can be divided into several types, one of which is historical interpretation which implies that the provisions of the Law are traced in terms of the birth 
of these provisions. Historical interpretation is distinguished between wetshistorische interpretatie and rechtshistosiche interpretatie. To carry out a wetshistorische interpretatie, it can be referred to starting from academic texts, the minutes of discussion in the DPR to the final discussion at the plenary session for the approval of the bill to become a law. In academic manuscripts, it can be seen the history of why this provision exists and why certain words are used in that provision.

The author in this case will examine the background of the formation of regulations regarding the obligation of attaching fingerprints to the deed in Article 16 paragraph (1) letter c Notary Position Law Number 2 of 2014, it is necessary to review the academic text of Notary Position Law Number 2 of 2014 and the developing responses. among legal practitioners and academics.

Regarding rechtshistorische interpretatie, historical tracing was carried out against legal institutions from time to time to time. What the Dutch scholars referred to as rechtshistorische interpretatie was not within the scope of the statutory approach, so that it was not included in the discussion of interpretation. The Rechtshistorische interpretatie falls within the scope of a historical approach. This approach really helps the author to understand the philosophy of the rule of law over time. The author can also understand the changes and developments in the philosophy that underlies these legal rules.

2. The Legislative Approach (Statute Aprroach)

The author uses the statutory principle lex posterior derogate legi priori, which means that the laws and regulations then set aside the previous laws and regulations. This principle is related to two laws and regulations that regulate the same problem, namely Law Number 30 of 2004 concerning Amendments to the Regulation of Notary Position of Staatsblad Number 3 of 1860 with Law Number 2 of 2014 concerning Amendments to Law Number 30. Year 2014. The author's statutory approach not only looks at the form of statutory regulations, but also examines the content of it, studies the ontological basis of the birth of laws, the philosophical basis of laws and the ratio legis of statutory provisions.

To understand the ontological basis of law, it is necessary to refer to the background of the birth of certain laws. This can be obtained from the Ministry or agency that submitted the bill. In the academic text, why the ministry or institution submitted the bill, it will reveal the need for the presence of this law. Therefore, the academic paper will contain a philosophical basis for why the law is needed. In addition, there are also minutes of discussion of laws at the House of Representatives. From a general viewpoint, debates in various kinds of hearings until the granting of approval will provide references regarding the birth of this law. To discuss ratio legis, it is necessary to teach interpretation or interpretation. This is because not all legal texts are clear.

\section{Legal Material Sources}

Based on the research method, the research materials to be used are primary data and secondary data, so the method used in this research includes two types, namely library research and field research.

1. Library Research

Library research is research that aims to obtain data that is used as a theoretical basis relating to the problems under study in order to support the data obtained during the study.

a. Primary Legal Materials

Primary legal materials are legal materials that are authoritative in nature, meaning they have authority. Primary legal materials consist of legislation, official records or 
minutes in the making of legislation and judges' decisions. The primary legal materials used in this research are:

- the 1945 Constitution of the Republic of Indonesia.

- Civil Code.

- Regulation of the Position of Notary at Staatsblad Number 3 of 1860.

- Law Number 30 of 2004 concerning Amendments to the Regulation of Notary Position of Staatsblad Number 3 of 1860.

- Law Number 2 of 2014 concerning Amendments to Law Number 30 of 2004 concerning the Position of Notary Public.

b. Secondary Legal Materials

Secondary legal materials are in the form of all legal publications that are not official documents. Publications on law include textbooks, legal dictionaries, legal journals, and comments on court decisions, as well as the results of written interviews and previous research.

The secondary legal materials used in this research are:

- Books that discuss Notary.

- Books that discuss Civil Procedure Law.

- Results of interviews with related parties in this study.

- The results of previous research.

c. Tertiary Legal Materials

Legal materials that provide an explanation for both primary and legal materials secondary law, in this case is the Big Indonesian Dictionary and the Legal Dictionary. The legal material is to broaden the writer's insight and to enrich the writer's point of view.

2. Field Research (Field Research)

Field research was carried out by going directly to the location by conducting interviews with research subjects to obtain data related to research to complement library research. The type of data collected in field research is data obtained directly from sources and respondents who know and are directly related to the problem under study. Respondents, namely people who are directly related to the object under study in a study. Selection of respondents based on criteria determined by the author, namely: Notary Abidin S. Panggabean, S.H, and Notary Herlina Ginting, SH., SpN.

\section{Data Collection Techniques}

1. Literature Research

2. In this library research, data collection methods can be done by reading, looking, listening. Therefore, secondary data collection is done by using the documentation method, namely by finding and collecting secondary data related to the object of research.

3. Field Research

4. In this field research, data collection was carried out by direct interviews with sources and respondents to obtain information or data.

5. Cyber Media

Cyber media is a data collection technique by collecting or searching for material related to the object of research or better known as data sources that come from the internet.

\section{Data Analysis}

Data analysis contains a description of the methods of analysis, namely, how to use the data that has been collected to be used in solving research problems. In this study, the data 
obtained from both the results of field research and literature will be analyzed descriptively qualitatively, namely primary data is selected and then presented based on with secondary data with the aim of obtaining a comprehensive and systemic picture, especially regarding matters relating to the problems under study.

\section{A. Affixing Fingerprints on Minute Deed of Notary Relating to Persons with Disabilities}

Law Number 2 of 2014 regulates several additional provisions, one of which is the regulation on fingerprints regulated in Article 16 paragraph (1) letter c, which stipulates: Notaries are required to attach letters and documents as well as fingerprints of the applicants on the minute deed. With the provisions of the article, it means that there has been recognition of fingerprints. Human fingerprints are used for identification purposes because human fingerprints are different from one another. Fingerprint identification (dactyloscopy) is frequently used within the police force.

In human anatomy, the thumb or thumb is one of the fingers on the hand. Fingerprints are the results of fingerprint reproduction, whether deliberately taken, imprinted with ink, or marks left on objects because they have been touched by the skin of the palms or feet. In the field of notaria ship in Indonesia, fingerprints are used as a substitute for signatures if a person is unable to sign, either because they are illiterate or because their hands are disabled or paralyzed, this is something that often occurs in Indonesia.

If the interlocutor has physical deficiencies, the obligation to use fingerprints has been regulated in Article 16 paragraph (1) letter $\mathrm{c}$ of Law Number 2 of 2014, however regarding the applicant who cannot put his fingerprints has not been explicitly regulated in the Law on the Position of Notary Public. This requires an arrangement that aims to provide legal certainty, for parties who commit a legal act that makes written evidence before a notary in the form of an authentic deed so that the parties receive the same protection in the eyes of the law, and clear legal arrangements, not only useful. for the benefit of the parties, it is also beneficial, for the notary in carrying out his position without any exception.

In Article 44 paragraph (1) of Law Number 2 of 2014, there is a requirement if an applicant cannot sign the deed due to a defect in his hand, then according to Article 44 paragraph (1) at the end of the deed, it explains the reasons why the applicant cannot sign the deed with his hand and therefore the tappers can give power verbally to a person appointed by the tappers on condition that the said tappers are present before the Notary Public and witnessed by 2 (two) identifying witnesses as a valid condition of a Notary deed which in comparison can be made as follows:

Mr. A has been introduced to me, Notary by two identifying witnesses who also came before me, Notary and I on my question Notary, claiming successively that Mr. B was born in on date nationality occupation residing in the street , the holder of Identity Card Number

Each deed read by a notary is attended by at least 2 (two) witnesses, identifying witnesses and instrument witnesses unless the statutory regulations stipulate otherwise, and the witness must meet the following requirements:

a. At least 18 (eighteen) years of age or already married.

b. Able to take legal actions.

c. Can sign and initials and.

d. Understand the language used in the deed.

e. Not having a marital relationship or blood relationship in a straight line up or down without restrictions on degrees and sideways up to the third degree with notaries or parties. 
Witnesses as referred to above must be recognized by the Notary or introduced to the Notary or explained about their identity and authority to the Notary by the parties where the recognition or statement regarding the identity and authority of the witness is expressly stated in the deed.

\section{B. Legal Consequences Against Notary Deed Regarding Persons with Disabilities Not Signing and Affixing Fingerprints on the Minutes of Deed}

Notary deeds which consist of 2 (two) types, namely deeds made before a Notary (deed Partij) and deeds made by Notaries (deed of officials / deed of relaas). Inclusion of fingerprints on the minutes of the deed does not act as a signature letter, which means that it is a substitute for the signature of the deed party and does not have any function in the official deed, as formulated in the provisions of Articles 44 and 46 of Law Number 2 of 2014, namely:

1. Immediately after the deed is read out, the deed is signed by each of the parties, witnesses, and notary public, except if there is an audience who is unable to sign it by stating the reason.

2. The reasons as referred to in paragraph (1) shall be clearly stated at the end of the deed.

In the provisions of Article 44 paragraph (1) and (2) Law Number 2 of 2014 confirms that the notary deed in the form of a party deed must be signed by the party, with the exception of the applicant who is unable to sign his / her signature, it must be done in a way the applicant explains to a notary public. the causes become an obstacle, such as an illiterate person or due to a temporary or permanent condition which results in the interviewer not being able to sign his / her signature in the deed, for example a handicap or paralyzed hand

The results of the interview with the Notary Herlina Ginting S.H which stated that if the tappers could not sign the deed because they did not have fingers, then at the end of the deed it was explained that the reasons for the notary being able to sign the deed by the notary must be stated explicitly in the deed and this statement will act as a substitute for the signature. Article 46 paragraphs 1 and 2 of Law Number 2 of 2014, confirms that a signature is not required in the official deed, if the provisions stipulated in the article are fulfilled, namely if an offender refuses to put his signature, it must be stated in the deed by stating the reasons or was not present at the closing of the deed, while the applicant has not signed the deed, this is still an authentic deed.

Fingerprints do not have any function in official deeds. Fingerprints affixed to underhand deeds are valid as substitutes for signatures, as long as they are legalized or legalized in the presence of a notary or an official appointed by law, namely a Notary, Chairman of BPN, Regent / Mayor or Head of Authority, as regulated in Article 1874 paragraph 2 of the Civil Code.

A deed that is born as an authentic deed and meets the requirements stipulated by law, then the deed is valid or can be considered as an authentic deed, until proven otherwise. Based on the explanation above and the opinion of scholars that if the objective conditions are not fulfilled, then the agreement is null and void, while if the subjective conditions are not fulfilled, then the agreement is not null and void but can be requested for cancellation. In other words, this agreement is valid or binding if it is not canceled by the judge at the request of the party entitled to request the cancellation.

In the power of proof of birth of a deed, the principle of public aprobant acta sese ipsa applies, which means that an official signature listed in the deed is the original until there is evidence to the contrary. The legal consequence of a deed will not lose its authenticity if the applicants do not sign, if the situation is described in the deed, so that if the applicant does not 
put a thumbprint or thumbprint as a substitute for a signature in making the authentic deed, it will not result in the legal consequence of the deed losing its authenticity.

The deed remains legally valid and still has value as an authentic deed even though it is not affixed with a thumb or thumbprint as a substitute for a signature. A notary deed becomes perfect and valid as a means of evidence in court if in the process of making it meets several requirements as mentioned above, namely, fulfills the legal requirements of the agreement Article 1320 Civil Code, meets the requirements of Article 1868 KUHPdt and Law Number 2 Year 2014 in conjunction with Law No. 30 of 2004, particularly in this writing, it complies with the provisions of Article 44 of Law No. 2 of 2014. Basically, an agreement remains valid as an agreement if it fulfills the validity requirements of the Article 1320 Civil Code agreement, even though the agreement does not meet the provisions of Article 1868 of the Civil Code, Law Number 30 of 2004, and Law Number 2 of 2014, especially regarding the affixing of a stamp. thumbs up at the end of the deed. The affixing a thumbprint / signature here results in whether a deed is authentic, the position of a deed which was originally an authentic deed if the thumbprint / signature is not affixed will turn into an under-hand deed. This will later affect the function of the deed as evidence in court.

\section{Authenticity of Notary Deed in Relation to Persons with Disabilities Not Signing and Putting Fingerprints on the Minutes of Deed}

A notary deed can be said to be an authentic deed or the authenticity of a Notary deed, namely:

1. Deed made by (door) or in front of a public official.

2. Deeds are made in the form and procedure (procedure) and conditions determined by law.

3. Public officials by or in front of whom the deed is drawn up must have the authority to make the deed.

The juridical characters of the Notary deed are:

1. Notarial Deed must be made in the form specified by law.

2. The Notary Deed is made because there is a request from the parties, and not the wish of the Notary.

3. Even though the notary deed includes the name of the Notary, in this case the notary is not a party together with the parties or the parties whose names are listed on the deed.

4. Has perfect evidentiary power, whoever is bound by a notary deed and it cannot be interpreted other than what is stated in the deed.

5. The cancellation of the binding power of a notary's deed can only be done upon the agreement of the parties whose names are stated in the deed. If there are those who do not agree, then the party who disagrees must submit an application to the general court so that the deed concerned is no longer binding for certain reasons that can be proven.

\section{Authenticity of Notary Deed if the Person Has Physical Disability}

An authentic deed which in the making is affixed with a signature at the end of the deed results in the deed becoming valid in the eyes of the law and can be used as perfect evidence, if in the process of making it, it has fulfilled the provisions of Article 1320 of the Civil Code as a condition for the validity of the agreement, Article 1868 Civil Code and the Law Number 2 of 2014 junto Law Number 30 of 2004. Notary deeds have perfect evidentiary power as evidence in the eyes of the law so that the Judge no longer needs to test the authenticity of the deed, congratulations no other party denies the contents of the deed.

Likewise, if a signature is affixed to a deed under hand, then the deed under the hand is still valid in the eyes of the law, and has perfect evidentiary power, as long as the party 
signing the deed does not deny that it is true that he has the signature on the deed under the hand. . Based on the results of an interview with Abidin S. Panggabean, SH, the Notary based in Medan City explained that if the tappers could not sign the deed with his hand, then at the end of the deed it is explained about a situation where the tappers cannot sign the deed and therefore uses another sign (ratification) of himself, namely writing using his mouth or feet which can be made with the following comparisons: "Immediately after this deed I, the Notary read it to the tappers and witnesses, then this deed was signed by Mr. A, the witnesses and I, the Notary, while Mr. B wrote a sign of his consent with his feet / mouth because he did not have hands. or fingers. "If there are parties who are unable to sign, then they must state the reasons and be clearly stated in the deed, as stipulated in the provisions of Article 44 paragraph (1) and (2) Law Number 2 of 2014.

A deed will not lose its authenticity. if the tappers do not put their signatures, as long as the situation is described in the deed, so that if the applicant does not put a thumbprint or thumbprint as a substitute for a signature in making the authentic deed, it will not bring legal consequences resulting in the deed losing its authenticity. The deed remains legally valid and still has the value as an authentic deed, even though there is no thumbprint or fingerprint as a substitute for the signature because the statement of the tappers, this is what the notary uses as the basis for ratification of the deed and this information is recognized as a substitute for the signature (signature surrogaat).

\section{Conclusion}

a. According to Article 16 paragraph (1) letter c of Law Number 2 of 2014, it is mandatory for the Notary to attach the face's fingerprints on the minuta deed. The notary asks the person to put a fingerprint (thumb / thumb) on the right and left which is attached to the deed, although there is no prohibition if there is a Notary who attaches a fingerprint to the deed with a finger other than the thumb, because there is no further explanation, in the Law on Notary Position regarding which fingerprints are attached to the minutas of deeds. The use of tappers' fingerprints on the minutes of deeds is not a substitute for the signature as referred to in Article 1874 of the Civil Code.

b. The legal implication of affixing the applicant's fingerprint on the Minuta of the Notary deed is that it will provide more legal certainty, because each person has different fingerprints, so that if in the future, there is a dispute, the party concerned cannot deny it. The affixing of fingerprints will also provide more legal force to the Notary deed product, so that it will have an impact on more legal protection,to the parties concerned, notaries and third parties, and can maintain orderly administration. Legal implications if the applicant's fingerprint is not affixed to the minimum deed in accordance with Article 16 paragraph (1) letter c of Law Number 2 of 2014, the Notary may be subject to administrative sanctions due to not being fulfilled by the Notary's obligations in carrying out his / her duties in the form of obligations contained in the Law Notary Position.

c. If an applicant is unable to put a fingerprint, he must state the reasons and be clearly stated in the deed so that the deed will not lose its authenticity. The deed remains legally valid and has value as an authentic deed. 


\section{Suggestion}

a. There is a need for an implementing regulation of Law Number 2 of 2014, so that the provisions of Article 16 paragraph (1) letter $\mathrm{c}$ do not cause multiple interpretations, even though the Indonesian Notary Association organization has determined which fingerprints must be affixed on a separate sheet and attached to the minimum. deed. It will be even more strengthening if the government establishes further regulations in government regulations as the implementation of this law.

b. Assessing the effectiveness of this fingerprint attachment, it should be taken into consideration for the government to implement the mandatory rules for attaching fingerprints to authentic deed products made by other authorized officials such as deeds of Land Deed Making Officials, Civil Registry deeds and other authentic deeds.

c. Notaries as state officials who are appointed by the government should maintain a professional attitude by obeying and implementing the regulations made for notary positions, both those made by the government and the Indonesian Notary Association organization regarding the obligation to put fingerprints on the minuta of the Notary deed in accordance with Article 16 paragraph (1) letter c Notary position Law Number 2 of 2014 and the Notary Code of Ethics. Apart from this, it will further assist the Notary in the process of proving the presence of an actor, as well as in fulfilling the principle of legal certainty in law enforcement to provide legal strength to the deed of law and legal protection for the Notary and the parties.

\section{References}

[1] Abdul Ghofur Anshori, Indonesian Notary Institute for Legal and Ethical Perspectives, Islamic University of Indonesia Press, Jakarta, 2009.

[2] Abdul Kadir Muhammad, Legal Professional Ethics, Citra Aditya Bakti, Bandung, 2001.

[3] Edmon Makarim, Notary and Electronic Signature, Rajawali Grafindo Persada, Jakarta, 2011.

[4] Habib Adjie, Aspects of Notary Accountability in Making Deeds, Mandar Maju, Bandung, 2011.

[5] G.H.S Lumban Tobing, Regulation of the Position of Notary Public, Erlangga, Jakarta, 1999.

[6] Habib Adjie, Aspects of Notary Accountability in Making Deeds, Mandar Maju, Bandung, 2011.

[7] Herlien Budiono and Albertus Sutjipto, Some Notes Regarding the Law on Notary Position, Indonesian Notary Association, Alumni, Bandung, 2005

[8] Irawan Soerodjo, Legal Certainty of Land Rights in Indonesia, Arkola, Surabaya, 2003.

[9] Indonesian Notary Association, Government Issues Inventory List (DIM) on the Draft Law on Amendments to Law Number 30 of 2004 concerning Notary Position, Jakarta, 2013.

[10] N. G. Yudara, Notary and Their Problems: Principles of Thought Regarding the Position and Function of a Notary and Notary Deed According to the Indonesian Legal System, Indonesian Notary Association, Jakarta, 2005.

[11] The Central Board of the Indonesian Notary Association, 100 Years of the Indonesian Notary Association, Past, Present and Future Indonesian Notary Identity, Gramedia Pustaka, Jakarta, 2008.

[12] R. Soegondo Notodisoerjo, Notariat Law in Indonesia An Explanation, Raja Grafindo, Jakarta, 1993.

[13] Tan Thong Kie, Book 2 of Notarial Studies and Miscellaneous Notary Practices, Ichtiar Baru Van Hoeve, Jakarta, 2000

[14] Wawan Setiawan, Position and Existence of General Officers and Land Deed Making Officials compared to the Position of State Administrative Officials according to the National Law System, Central Executive of Land Deed Making Officials, Jakarta, 2001.

[15] The 1945 Constitution of the Republic of Indonesia;

[16] Code of Civil law; 
[17] Regulation of the Position of Notary at Staatblaad Number 3 of 1860 ;

[18] Law Number 2 of 2014 concerning Amendments to Law Number 30 of 2004 concerning the Position of Notary Public. 